\title{
ANALISA MOTIVASI KERJA PEGAWAI PT. ZTE INDONESIA
}

\author{
Sapto Hadi Imambachri ${ }^{1}$ \\ Dosen Prodi D-III Sekretari Universitas Pamulang \\ saptohadi29@gmail.com \\ Oleh : Tiara Chandika ${ }^{2}$ \\ Mahasiswa Prodi D-III Sekretari Universitas Pamulang \\ tiarachandika.tc@gmail.com
}

\begin{abstract}
ABSTRAK-Penelitian yang berjudul Analisa Motivasi Kerja Pegawai PT ZTE Indonesia bertujuan untuk mengetahui kepuasan kerja karyawan, kinerja dan hambatan- komunikasi yang terjadi pada PT. ZTE Indonesia setelah PT ZTE Indonesia terkena larangan selama tujuh tahun tanpa suplai komponen yang berteknologi tinggi seperti chipset Qualcomm oleh Amerika Serikat pada tahun 2018. Penelitian deskriptif kualitatif ini dilaksanakan dengan menggunakan kuesioner kepada 25 responden dan wawancara langsung terhadap pegawai PT ZTE Indonesia yang digunakan sebagai data primer serta menggunakan dokumen pendukung yang digunakan sebagai data sekunder. Kuesioner diberikan kepada responden dengan menggunakan skala likert kemudian di Analisa berdasarkan jumlah responden yang memilih untuk elemen elemen yang ada pada skala Likert tersebut, maka berdasarkan analisa yang penulis dapatkan bahwa kepuasan kerja adalah 91,2\%, komunikasi 90\%, kinerja kerja 99,32\% dan dikaitan dengan tingkat kehadiran karyawan 93,9\% maka dapat disimpulkan bahwa karyawan PT.ZTE Indonesia mempunyai motivasi yang tinggi terhadap pekerjaan mereka. Meskipun demikian ruang perbaikan masih harus diperhatikan, terutama yang berdasarkan pengisian kuesioner pada elemen Setuju= S , masih cukup banyak.
\end{abstract}

Kata Kunci : Motivasi Kerja, Kepuasan Kerja, Kinerja, Hambatan

ABSTRACT-The research entitled Analysis of Employee Work Motivation at PT ZTE Indonesia aims to determine employee job satisfaction, performance and communication barriers that occur at PT. ZTE Indonesia after PT ZTE Indonesia was banned for seven years without the supply of high-tech components such as Qualcomm chipsets by the United States in 2018. This descriptive qualitative research was carried out using a questionnaire to 25 respondents and direct interviews with PT ZTE Indonesia's employees that were used as data primary as well as using supporting documents that are used as secondary data. The questionnaire was given to respondents using a Likert scale and then analyzed based on the number of respondents who chose to elements - elements on the Likert scale, then based on the analysis that the authors get that job satisfaction is $91.2 \%$, communication $90 \%$, work performance $99,32 \%$ and associated with an attendance rate of $93.9 \%$, it can be concluded that the employees of PT. ZTE Indonesia have high motivation towards their work. Nevertheless, room for improvement still needs to be considered, especially those based on filling out the questionnaire on the Agree $=S$ element, there are still quite a lot.

Keywords: Work Motivation, Job Satisfaction, Performance, Obstacles 


\section{PENDAHULUAN}

\section{Latar Belakang Masalah}

Bisnis telekomunikasi merupakan bisnis yang saat ini sedang dalam kenaikan yang cukup signifikan di era globalisasi saat ini. Dalam hal ini khususnya PT ZTE INDONESIA dalam bersaing dengan perusahaan telekomunikasi lainnya yang ada di Indonesia untuk memenuhi jaringan kabel atau internet dengan jangkauan yang lebih luas lagi.

Disamping itu banyak perusahaan berbasis teknologi atau komunikasi yang banyak bermunculan di Indonesia sehingga persaingan di dunia telekomunikasi semakin tajam. Contohnya dengan datangnya perusahaan asing seperti Huawei Tech Investment Tbk, Telekomunikasi Seluler dan masih banyak lagi di seluruh wilayah Indonesia.

Untuk dapat bersaing dengan perusahaan yang bergerak dibidang jasa telekomunikasi lainnya, perusahaan harus mempunyai keunggulan kompetitif yang sangat sulit ditiru, yang hanya akan diperoleh oleh karyawan yang produktif, inovatif, kreatif, selalu bersemangat dan loyal. Faktor yang digunakan untuk meningkatkan kinerja karyawan diantaranya adalah motivasi kerja. Kinerja kerja karyawan bisa dilandasi dengan hasil pola pikir dan tenaga dari seorang karyawan terhadap pekerjaannya.

Pembahasan tentang motivasi kerja pegawai tidak hanya bisa dilepaskan dari kenyataan bahwa dapat dicapai apabila semua harapannya dapat dipenuhi dalam melaksanakan tugas pekerjaannya. Kinerja kerja karyawan berhubungan dengan harapan pegawai terhadap atasan, rekan kerja dan terhadap pekerjaan itu sendiri. Di dalam lingkungan kerja, karyawan tidak mendapatkan apa yang didapatkan seperti peluang promosi yang adil, pendapatan yang baik, rekan kerja dan atasan yang menyenangkan serta kepuasan terhadap pekerjaan itu sendiri, maka kinerja karyawan akan buruk.

Motivasi terbentuk dari sikap (attitude) seorang pegawai dalam menghadapi situasi (situation) kerja. Motivasi merupakan kondisi yang menggerakan diri pegawai yang terarah untuk mencapai tujuan organisasi. (A.A.Anwar Prabu Mangkunegara, 2001:68) Sikap mental merupakan kondisi mental yang mendorong diri pegawai untuk berusaha mencapai prestasi kerja secara maksimal. Sikap mental seorang pegawai harus sikap mental yang siap secara psikofisik (siap secara mental, fisik, tujuan, dan situasi). Artinya seorang pegawai harus 
siap mental, mampu secara fisik, memahami tujuan utama, dan target kerja yang akan dicapai, mampu memanfaatkan, dan menciptakan situasi kerja.

Sikap mental yang siap secara psikofisik terbentuk karena pegawai mempunyai "MODAL" dan "KREATIF" . Modal merupakan singkatan dari $\mathrm{M}=$ Mengolah, $\mathrm{O}=$ Otak, $\mathrm{D}=$ Dengan, $\mathrm{A}=$ Aktif, $\mathrm{L}=$ Lincah, sedangkan Kreatif merupakan singkatan dari $\mathrm{K}=$ Keinginan maju, $\mathrm{R}=$ Rasa ingin tahu tinggi, $\mathrm{E}=$ Energik, $\mathrm{A}=$ Analisis sistematik, $\mathrm{T}=$ Terbuka dari kekurangan, $\mathrm{I}=$ Inisiatif tinggi, $\mathrm{F}=$ Fikiran luas (A.A Anwar Prabu Mangkunegara, 2001:68). Sehingga pegawai tersebut mampu mengolah otak aktif dan lincah, memiliki keinginan maju, rasa ingin tahu tinggi, energik, analisis sistematik, terbuka untuk menerima pendapat, inisiatif tinggi, dan pikiran luas terarah.

Sekalipun motivasi merupakan hal yang bersifat penting, namun motivasi itu sendiri cukup sulit untuk dilakukan. Untuk memahami motivasi secara lebih mendalam maka harus dipahami pula bahwa di dalam organisasi public akan terjadi interaksi dan aktivitas baik yang bersifat positif maupun negatif dalam hubungannya dengan pelaksanaan tugas. Ada berbagai macam dorongan dalam upaya untuk memperluas pegawai yang mempengaruhi efisiensi dan kualitas dari operasi pemerintah seringkali menjadi pusat perbaikan produktivitas. Analisis yang lebih mengkonsentrasikan pada kinerja kerja pegawai akan lebih memberikan penekanan dua faktor utama, yaitu keinginan atau motivasi dari pegawai untuk bekerja yang kemudian akan menghasilkan usaha-usaha pegawai tersebut dan kemampuan dari pegawai untuk bekerja. Dengan demikian motivasi yang diharapkan dari pegawai adalah bahwa dari motivasi dan kemampuan tersebut dapat mempengaruhi kinerja kerja pegawai. Apabila motivasi tinggi dengan didukung oleh kemampuan yang tinggi maka kinerja kerja pegawai juga tinggi dan sebaliknya. Hanya saja yang menjadi permasalahannya adalah jika motivasi tinggi tetapi tanpa didukung oleh kemampuan yang cukup, maka pada prinsipnya pegawai tersebut memiliki minat yang tinggi namun kemampuannya kurang. Jika ini terjadi, maka pegawai tersebut harus di tingkatkan kemampuannya baik melalui jalur kursus, pendidikan atau pelatihan (training). Sedangkan sebaliknya, jika pegawai tersebut memiliki kemampuan yang cukup namun tidak mempunyai motivasi yang tinggi, maka ini dapat diselesaikan dengan memberikan incentive atau penghargaan. Dengan incentive tersebut maka orang yang memiliki kemampuan akan termotivasi.

Dalam hal ini pun PT. ZTE Indonesia 
JURNAL ILMIAH ILMU SEKRETARI/ADMINISTRASI PERKANTORAN p-ISSN 2354-6557 | e-ISSN 2614-5456

termasuk perusahaan yang dapat memberikan kesenjangan sosial yang cukup baik bagi para karyawannya, dari salary sepadan yang diberikan hingga fasilitas kesehatan yang dibutuhkan bagi para karyawan. PT. ZTE Indonesia adalah salah satu perusahaan yang menganggap karyawan sebagai asset penting bagi perusahaan dengan memberikan pelayanan yang cukup memuaskan dan sesuai dengan kebutuhan karyawan dan dapat memberikan work life balance yang sangat baik.

PT. ZTE Indonesia juga memberikan harapan kerja yang baik terhadap karyawannya dimana dapat memfasilitasi karyawan dengan cukup baik dari soal tunjangan, lingkungan kerja, rekan kerja dan suasana kenyamanan dalam bekerja di berikan oleh PT. ZTE Indonesia. Benefit yang di dapatkan karyawan pun cukup memuaskan bagi para karyawan itu sendiri. Perusahaan juga memberikan peluang karir yang baik untuk para karyawan itu sendiri dan setiap karyawan bisa juga menambah banyak ilmu tentang dunia pertelekomunikasian saat ini.

Di tahun 2018, PT ZTE Indonesia sempat mengalami penurunan kualitas kerja dikarenakan ZTE terkena larangan selama tujuh tahun tanpa suplai komponen yang berteknologi di Amerika Serikat, semisal chipset Qualcomm. PT ZTE pun sempat dikabarkan akan menutup bisnisnya di Indonesia. Rekanan ZTE di Indonesia seperti Indosat Ooredoo dan Telkomsel telah mengakhiri kerjasama dalam penyediaan jaringan. Selain itu, sebagian pegawai ZTE yang merupakan outsourcing dari PT China Comservice Indonesia (CCSI) yang berada di wilayah Jakarta akan dialihkan sementara ke Indosat Ooredoo. Jumlah pegawai outsourcing yang terkena dampak dari hal ini pun ditaksir mencapai 100 orang karyawan. Terhentinya pekerjaan ini pun berdampak buruk bagi sebagian karyawan ZTE yang ada di divisi lain. Sebagian dari mereka mengkhawatirkan apakah mereka akan bernasib sama dengan karyawan ZTE lainnya yang terkena PHK. Bahkan atas kejadian ini semua pekerjaan yang bersangkutan dengan Customer ataupun kegiatan di Back office terhenti sampai waktu yang tidak ditentukan, pastinya ini sangat mengurangi motivasi dan kinerja karyawan. Bahkan sebagian karyawan selama hampir dari dua bulan tidak diperbolehkan untuk melakukan kegiatan apapun tetapi pihak management tetap meminta sebagian karyawan tetap datang ke kantor walaupun tidak melakukan hal operasional. Walaupun sebagian karyawan tidak melakukan kegiatan apapun mereka tetap menjalankan kewajiban mereka sebagai keryawan dengan tetap datang ke kantor dan melakukan kegiatan pekerjaan yang bisa 
mereka lakukan dengan kerja manual dan tidak menggunakan sistem, dikarenakan tidak boleh ada satupun karyawan yang bisa menggunakan sistem sampai waktu yang ditentukan oleh pihak Head Quarter.

PT ZTE Indonesia merupakan salah satu perusahaan yang menginginkan karyawannya bekerja dengan baik sesuai dengan pengalaman yang dimiliki masingmasing karyawan, oleh karna itu dalam hal seperti ini pun pihak management masih memikirkan bagaimana caranya agar karyawan tetap terfokus pada setiap pekerjaan agar setiap karyawan tetap mempunyai tanggung jawab terhadap pekerjaannya dan agar tidak berdampak banyaknya pekerjaan yang menumpuk penulis mengidentifikasikan masalah dalam beberapa yaitu sebagai berikut :

1. Menurunnya kepuasan kerja pada PT. ZTE Indonesia

2. Kurangnya komunikasi mengenai kepastian kerja pada PT. ZTE Indonesia

3. Menurunnya kualitas kinerja kerja pada PT. ZTE Indonesia

4. Status karyawan outsourcing lebih banyak disbanding karyawan tetap

5. Banyaknya karyawan yang terkena PHK pada PT. ZTE Indonesia

\section{Pembatasan Masalah}

Agar observasi ini lebih terarah dan tidak dikemudian hari dimana perusahaan sudah kondusif kembali. Dikarenakan pihak dari ZTE pun masih mencoba untuk menjalankan bisnisnya dengan beberapa customer yang masih terikat pekerjaan dengan PT ZTE Indonesia. Maka dari itu, maksud dari observasi ini yaitu untuk mengetahui tentang bagaimana peningkatan motivasi kerja karyawan pada PT. ZTE Indonesia.

Berdasarkan uraian diatas, maka observasi ini akan mengkaji tentang motivasi kerja karyawan dengan mengambil judul yaitu, "Analisa Motivasi Kerja Pegawai PT. ZTE Indonesia"

\section{Identifikasi Masalah}

Berdasarkan uraian latar belakang maka menyimpang dari topik dipersoalkan maka penulis memberi batasan permasalahan observasi pada :

1. Menurunnya kepuasan kerja pada PT. ZTE Indonesia

2. Kurangnya komunikasi mengenai kepastian kerja pada PT. ZTE Indonesia

3. Menurunnya kualitas kinerja kerja pada PT. ZTE Indonesia

\section{Rumusan Masalah}

Untuk membatasi pembahasan masalah yang ada dan berdasarkan hasil observasi penulis, maka dalam kesempatan ini penulis merumuskan permasalahan dalam analisa ini 
JURNAL ILMIAH ILMU SEKRETARI/ADMINISTRASI PERKANTORAN yaitu :

1. Bagaimana kepuasan kerja pada PT. ZTE Indonesia ?

2. Apakah komunikasi mengenai kepastian kerja pada PT. ZTE Indonesia sudah efektif?

3. Bagaimana tingkat kinerja kerja pada PT. ZTE Indonesia ?

\section{Tujuan dan Manfaat Observasi}

\section{Tujuan Observasi}

a. Untuk mengetahui kepuasan kerja karyawan PT. ZTE Indonesia

b. Untuk mengetahui bagaimana tingkat kinerja kerja karyawan PT. ZTE Indonesia

c. Untuk mengetahui kesulitan komunikasi seperti apa ditemui pada PT. ZTE Indonesia

\section{Manfaat Observasi}

a. Observasi ini pada prinsipnya bermanfaat bagi penulis dalam hal mengimplementasikan teori-teori yang penulis dapatkan selama kuliah

b. Sebagai bahan masukan untuk perusahaan demi peningkatan yang baik bagi karyawan itu sendiri

c. Sebagai salah satu sarana bagi penulis untuk mendukung program pemerintah dalam mewujudkan
p-ISSN 2354-6557 | e-ISSN 2614-5456

peningkatan budaya menulis ilmiah yang bisa dijadikan referensi bagi semua kalangan, baik kalangan akademisi maupun masyarakat umum.

\section{Metode Penulisan}

Metode Penulisan yang digunakan dalam observasi ini adalah deskriptif-kualitatif yang menjelaskan tentang motivasi kerja yang diperoleh melalui :

1. Observasi selama melakukan pekerjaan di PT. ZTE Indonesia dan membandingkan dengan teori yang telah di dapat di bangku perkuliahan serta literature penunjang lainnya. Lokasi observasi ini bertempat di PT. ZTE Indonesia, BFI Tower 1t 8 Sunburst CBD Lot. 1.2, Jalan Kapten Soebijanto Djojohadikusumo, BSD City, Lengkong Gudang Serpong Tangerang Selatan, Banten 15321

2. Melalui Wawancara langsung kepada para karyawan PT. ZTE Indonesia

3. Kuisoner yang di bagikan dan diisi langsung oleh karyawan PT. ZTE Indonesia

HASIL DAN PEMBAHASAN

Upaya Manajemen PT ZTE Indonesia dalam Memotivasi Kerja Karyawan Untuk mencapai tingkat motivasi 
kerja yang tinggi atau yang diinginkan perusahaan, maka pihak manajemen PT ZTE Indonesia melakukan upaya dan program peningkatan motivasi guna tercapainya produktivitas kerja karyawannya. Prinsip dan tujuan dari program-program motivasi kerja dilingkungan perusahaan adalah bagaimana menjadikan karyawan/tenaga kerja merupakan aset atau bagian dari perusahaan dan bukan merupakan alat produksi, sehingga karyawan merasa sebagai bagian dari perusahaan. Adapun berbagai upaya yang dilakukan oleh manajemen perusahaan yang berkelanjutan guna menumbuhkan, mempertahankan, dan meningkatkan motivasi kerja karyawannya adalah sebagai berikut :

1. Segala ketentuan pemerintah mengenai ketenagakerjaan sepenuhnya dijalankan dan diterapkan dilingkungan kerja PT. ZTE Indonesia oleh manajemen perusahaan, sehingga tidak ada keluhan dari para karyawan tentang hal-hal yang sudah ditentukan (normatif).

2. Disamping kompensasi berupa gaji (normatif), manajemen PT ZTE Indonesia juga memberikan kebijakan berupa uang makan dan transport atau juga claim overtime kepada karyawan.

3. Bagi karyawan yang mempunyai masa kerja lama, mendapatkan kebijakan tunjangan masa kerja yang besarnya sesuai dengan masa kerja karyawan yang bersangkutan. Hal ini sesuai dengan teori Maslow dalam Stephen P. Robins (2008:2000), yaitu dengan memberikan kebijakan tunjangan masa kerja yang termasuk dalam kebutuhan order rendah terutama dipenuhi secara internal (dengan upah, kontrak serikat buruh, dan masa kerja). Disamping itu, perusahaan juga memberlakukan sistem penggajian/kompensasi khusus/tertentu, dimana karyawan yang rajin dan bekerja melebihi target yang telah ditentukan akan mendapatkan gaji yang lebih banyak dari karyawan yang bekerja biasa-biasa saja. Hal ini dapat menciptakan dan memacu motivasi kerja karyawan yang cukup signifikan.

4. Pada bagian-bagian atau unit-unit kerja tertentu, dimana bagian-bagian tersebut memiliki resiko dan tanggung jawab yang sangat besar dan beresiko terhadap pekerjaan atau produk akhir / finished good. Hal ini sesuai dengan pendapat Maslow dalam Desler (2008:331) yaitu secara teoritis motivasi terbentuk karena manusia memiliki lima kategori kebutuhan pokok, dalam hal ini termasuk dalam kategori kebutuhan rasa aman, yaitu kebutuhan akan perlindungan dari ancaman, bahaya, pertentangan, dan lingkungan hidup. 
JURNAL ILMIAH ILMU SEKRETARI/ADMINISTRASI PERKANTORAN p-ISSN 2354-6557 | e-ISSN 2614-5456

5. Guna menjaga kesehatan para karyawannya, PT ZTE Indonesia memberikan fasilitas Medical Check $U p$ dalam sekali setahun. Hal ini dimaksudkan untuk menjaga kesehatan karyawan dan memantau perkembangan kondisi kesehatan karyawan.

6. Disamping Tunjangan Hari Raya (THR) yang bersifat normatif, setiap tahun karyawan juga diberikan bonus kinerja yang besarnya disesuaikan dengan masa kerja dan prestasi kerja..

7. Perusahaan mengadakan rekreasi bagi seluruh karyawan setiap tahun dengan tujuan refreshing dan meningkatkan kebersamaan sesuai kondisi perusahaan.

8. Guna memacu produktivitas, perusahaan menerapkan sistem target dan memberikan reward bagi kelompok kerja yang mampu memenuhi atau melebihi target yang diterapkan dan memberikan treatment / perlakuan khusus bagi kelompok yang tidak memenuhi target kerja yang sudah ditentukan oleh manajemen perusahaan.

9. Secara periodik berdasar kriteria khusus, perusahaan menunjuk karyawan terbaik/teladan dalam setiap levelnya. Diberikan penghargaan (piagam, piala, uang, dll), serta foto dipasang di ruang tamu perusahaan.

\section{Jenis Data}

Untuk memperoleh data yang dibutuhkan, maka dalam observasi ini menggunakan data :

1. Data Primer

Adalah data yang diperoleh secara langsung dari objek yang diamati pada waktu observasi di PT. ZTE Indonesia

2. Data Sekunder

Adalah data data yang diperoleh dari buku-buku atau literature sebagai penunjang observasi

\section{Metode Pengumpulan Data}

\section{Kuisioner}

Pengumpulan data dengan menggunakan kuisoner yang dibagikan kepada 25 karyawan PT.ZTE Indonesia secara acak. Dengan pernyataan sesuai dengan table 2.1 dan 2.2 
Tabel 2.1 Daftar Pernyataan Kuisoner Variabel Motivasi Kerja

\begin{tabular}{|c|c|c|c|c|c|c|}
\hline \multirow{2}{*}{$\mathrm{NO}$} & \multirow{2}{*}{ ITEM PERNYATAAN } & \multicolumn{5}{|c|}{ PILIHAN JAWABAN } \\
\hline & & SS & $\mathrm{S}$ & KS & $\mathrm{TS}$ & STS \\
\hline 1 & $\begin{array}{l}\text { Saya merasa bahwa kebutuhan fisiologis sudah } \\
\text { terpenuhi di perusahaan ini }\end{array}$ & & & & & \\
\hline 2 & Saya merasa diperlakukan adil di perusahaan ini & & & & & \\
\hline 3 & $\begin{array}{l}\text { Saya merasa tenang dalam bekerja karena } \\
\text { tersedianya jaminan kesehatan dari perusahaan ini } \\
\text { Bekerja pada perusahaan ini, dapat menjamin } \\
\text { kehidupan saya dihari tua }\end{array}$ & & & & & \\
\hline 5 & $\begin{array}{l}\text { Saya merasa senang karena karyawan di perusahaan } \\
\text { ini bisa menerima saya sebagai partner yang baik }\end{array}$ & & & & & \\
\hline 6 & $\begin{array}{l}\text { Saya selalu dilibatkan dalam pertemuan atau rapat } \\
\text { dalam mengambil keputusan perusahaan }\end{array}$ & & & & & \\
\hline 7 & $\begin{array}{l}\text { Atasan saya selalu memberikan pujian apabila saya } \\
\text { menjalankan tugas pekerjaan dengan hasil } \\
\text { memuaskan }\end{array}$ & & & & & \\
\hline 8 & $\begin{array}{l}\text { Perusahaan memberikan kesempatan bagi } \\
\text { karyawan untuk mengembangkan potensi yang ada } \\
\text { pada dirinya untuk lebih maju }\end{array}$ & & & & & \\
\hline 9 & $\begin{array}{l}\text { Saya merasa tertantang untuk menyelesaikan tugas } \\
\text { yang diberikan }\end{array}$ & & & & & \\
\hline 10 & $\begin{array}{l}\text { Saya merasa senang selama pekerjaan saya } \\
\text { diperusahaan ini di akui oleh atasan }\end{array}$ & & & & & \\
\hline
\end{tabular}


Tabel 2.2 Daftar Pernyataan Kuisoner Variabel Kinerja Pegawai

\begin{tabular}{|c|c|c|c|c|c|c|}
\hline \multirow{2}{*}{ NO } & \multirow{2}{*}{ ITEM PERNYATAAN } & \multicolumn{5}{|c|}{ PILIHAN JAWABAN } \\
\hline & & SS & $\mathrm{S}$ & $\mathrm{KS}$ & TS & STS \\
\hline 1 & $\begin{array}{l}\text { Saya selalu berusaha untuk menyelesaikan pekerjaan dengan penuh } \\
\text { rasa tanggung jawab untuk mencapai hasil yang maksimal }\end{array}$ & & & & & \\
\hline 2 & $\begin{array}{l}\text { Saya selalu berusaha mencapai target kerja yang ditetapkan } \\
\text { oleh perusahaan }\end{array}$ & & & & & \\
\hline 3 & $\begin{array}{l}\text { Saya selalu bekerja sesuai standard mutu yang telah } \\
\text { ditetapkan oleh perusahaan }\end{array}$ & & & & & \\
\hline 4 & $\begin{array}{l}\text { Saya selalu berusaha menyelesaikan pekerjaan-pekerjaan } \\
\text { yang diberikan sesuai dengan target waktu kerja yang telah } \\
\text { ditentukan }\end{array}$ & & & & & \\
\hline 5 & $\begin{array}{l}\text { Pengetahuan akan pekerjaan dapat membantu saya dalam } \\
\text { mengatasi permasalahan yang muncul pada saat bekerja }\end{array}$ & & & & & \\
\hline 6 & $\begin{array}{l}\text { Saya dapat mengerjakan pekerjaan dengan efektif dan efisien } \\
\text { sehingga tidak perlu banyak intruksi dan umpan balik dari } \\
\text { atasan saya }\end{array}$ & & & & & \\
\hline 7 & $\begin{array}{l}\text { Kreativitas yang tinggi dapat membantu saya mencapai hasil } \\
\text { kerja yang lebih baik }\end{array}$ & & & & & \\
\hline 8 & Saya selalu memberikan ide-ide untuk kemajuan perusahaan & & & & & \\
\hline 9 & $\begin{array}{l}\text { Saya selalu bersedia untuk bekerja sama dengan sesama } \\
\text { karyawan perusahaan lain }\end{array}$ & & & & & \\
\hline 10 & $\begin{array}{l}\text { Saya selalu berusaha menyelesaikan pekerjaan lebih cepat } \\
\text { dari waktunya agar saya dapat mengerjakan pekejaan } \\
\text { berikutnya }\end{array}$ & & & & & \\
\hline 11 & $\begin{array}{l}\text { Saya selalu hadir tepat waktu sesuai dengan jadwal yang } \\
\text { sudah ditetapkan ditempat kerja }\end{array}$ & & & & & \\
\hline 12 & $\begin{array}{l}\text { Saya memiliki semangat untuk melaksanakan pekerjaan- } \\
\text { pekerjaan baru yang diberikan oleh perusahaan }\end{array}$ & & & & & \\
\hline
\end{tabular}

Sumber : Hasil review literatur 


\section{Wawancara}

Metode wawancara adalah dialog antara pewawancara dengan terwawancara untuk memperoleh informasi yang lengkap, tepat dan jelas secara langsung. Wawancara yang dilakukan, ditujukan kepada karyawan PT.
ZTE Indonesia.

Metode ini untuk mengetahui tentang motivasi kerja yang dilakukan pada PT. ZTE Indonesia. Daftar pertanyaan dalam wawancara terlihat pada tabel 2.3

Tabel 2.3 Pedoman Wawancara

\begin{tabular}{|c|c|}
\hline NO & ITEM PERNYATAAN \\
\hline 1 & Bagaimana sejarah berdirinya PT. ZTE Indonesia? \\
\hline 2 & Bagaimana struktur organisasi PT. ZTE Indonesia saat ini? \\
\hline 3 & Bagaimana jam kerja yang ditetapkan oleh manajemen perusahaan? \\
\hline 4 & $\begin{array}{l}\text { Menurut anda, apakah bekerja pada perusahaan ini dapat menjamin kehidupan di hari tua } \\
?\end{array}$ \\
\hline 5 & Apakah anda sudah puas dan merasa cukup bekerja di PT. ZTE Indonesia? \\
\hline 6 & $\begin{array}{l}\text { Melalui saluran komunikasi apa manajemen perusahaan bisa mengetahui dan menyerap } \\
\text { keluhan, kritik dan saran dari seluruh karyawannya? }\end{array}$ \\
\hline 7 & $\begin{array}{l}\text { Bagaimana cara anda memotivasi diri sendiri agar tetap bekerja sesuai dengan tanggung } \\
\text { jawab anda ? }\end{array}$ \\
\hline 8 & $\begin{array}{l}\text { Apakah anda siap bekerja dengan baik dan siap mempertanggung jawabkan hasil kerja } \\
\text { anda? }\end{array}$ \\
\hline 9 & Kesulitan apa yang di hadapi dalam memotivasi karyawan? \\
\hline 10 & $\begin{array}{l}\text { Upaya apa saja yang dilakukan manajemen untuk mengatasi kesulitan dalam penerapan } \\
\text { motivasi kerja pegawai ? }\end{array}$ \\
\hline
\end{tabular}

Sumber : Hasil review literatur 


\section{Metode Analisis Data}

Dalam penelitian ini, metode analisis data yang digunakan yaitu menggunakan metode analisis data secara analisis deskriptif. Metode analisis deskriptif adalah suatu metode dalam meneliti status sekelompok manusia, suatu objek, suatu set kondisi, suatu sistem pemikiran atau suatu kilas peristiwa pada masa sekarang. Tujuannya adalah untuk membuat deskriptif gambaran atau lukisan secara sistematik, factual, dan akurat mengenai fakta-fakta, sifat serta hubungan antara fenomena yang diselidiki (Nazir,1998:63). Observasi ini meggunakan metode analisis

deskriptif dimaksudkan agar memperoleh gambaran dan data secara sistematis tentang bagaimana hal yang berkaitan erat dengan motivasi kerja karyawan PT. ZTE Indonesia.

\section{Tingkat Motivasi Kerja Karyawan PT. ZTE Indonesia}

Untuk mengetahui sejauh mana tingkat motivasi kerja karyawan PT. ZTE Indonesia, yaitu berdasarkan keterangan hal-hal berikut :

1. Pengamatan / observasi langsung terhadap karyawan di lingkungan PT. ZTE Indonesia pada bagian-bagian :

a. Departemen Quality Control

b. Project c. Umum

d. Pengamatan umum pada semua ruangan kerja lingkungan kantor.

2. Wawancara / Interview langsung dengan karyawan PT. ZTE Indonesia pada bagian :

a. Human Resource Departement

b. Staff umum bagian kesejahteraan karyawan kontrak

c. Staff umum bagian kesejahteraan karyawan permanen

d. Roll Out Manager

e. Cross check atas beberapa ketentuan dan kebijakan perusahaan yang diberlakukan kepada karyawan.

f. Cross check data karyawan Diperoleh data sebagai berikut:

Berdasarkan pengamatan dan observasi langsung yang dilakukan pada bulan Agustus 2018 di lingkungan perkantoran PT. ZTE Indonesia, seluruh karyawan pada saat jam kerja bekerja semua sesuai dengan bidang tugasnya masingmasing. Jam kerja yang ditetapkan oleh pihak perusahaan PT. ZTE Indonesia yaitu: Hari Senin - Jum'at : 08:30 - 17:30 WIB, Selebihnya diperhitungkan overtimel lembur yang dibayar sesuai dengan ketentuan Departemen tenaga kerja (Depnaker) / Pemerintah. 
Efisiensi dan efektivitas kerja terlihat semua unit kerja, sehingga tidak kelihatan ada karyawan yang tidak bekerja. Pada saat jam istirahat (jam 12:00 - 13:00), seluruh karyawan tidak boleh ada yang berada dalam ruang kerjanya dan perusahaan menyediakan tempat istirahat bagi karyawan yang cukup luas dengan kualitas bangunan yang representatif. Meeting kordinasi dan konsolidasi pada semua bagian dan departemen yang diselenggarakan secara periodic (minimal 1 bulan 1 kali) yang diikuti seluruh karyawan pada bagian tersebut dan dipimpin oleh Roll Out Manager.

Setiap minimal 2-3 bulan diadakan dialog dan konsolidasi yang dihadiri pada

Berdasarkan wawancara / interview dengan beberapa karyawan diperoleh data sebagai berikut :

Perusahaan melalui Human Resource Departement mempunyai beberapa saluran komunikasi guna mengetahui dan menyerap keluhan, kritik, dan saran dari seluruh karyawan antara lain :

oleh seluruh manager dan seluruh karyawan sampai pada level terbawah guna mengetahui perkembangan pekerjaan, menginformasikan tentang kondisi perusahaan, menyerap aspirasi dan keluhan.

\section{Profil Responden}

\section{Klasifikasi responden berdasarkan jenis kelamin}

Tabel 2.4 Klasifikasi responden berdasarkan jenis kelamin

\begin{tabular}{ccc}
\hline Jenis Kelamin & Jumlah (org) & $\%$ \\
\hline Pria & 21 & $84 \%$ \\
Wanita & 4 & $16 \%$ \\
Jumlah & 25 & $100 \%$ \\
\hline
\end{tabular}

Sumber : Data diolah, 2018

Tabel 3.1 menunjukkan bahwa berdasarkan bahwa dari 25 pegawai yang dijadikan sampel terdapat 21 orang $(84 \%)$ berjenis kelamin wanita. data yang diperoleh di atas terlihat kelamin Pria dan 4 orang $(16 \%)$ berjenis 


\section{Klasifikasi Responden Berdasarkan Jabatan}

Tabel 2.5 Klasifikasi Responden Berdasarkan Jabatan

\begin{tabular}{lll}
\hline Jabatan & Jumlah (org) & $\%$ \\
\hline Staff & 14 & $56 \%$ \\
Supervisior & 8 & $32 \%$ \\
Project Manager & 3 & $12 \%$ \\
Lain-lain & 0 & $0 \%$ \\
Jumlah & 25 & $100 \%$ \\
\hline
\end{tabular}

Sumber : Data diolah, 2018

Tabel di atas menunjukkan bahwa dari 25 atau 56\% dari jumlah sampel. 8 orang orang pegawai yang dijadikan sampel supervisior dan 3 orang sebagai Project didominasi oleh staff, sebanyak 14 orang Manager.

\section{Klasifikasi Responden Berdasarkan Umur}

Tabel 2.6 Klasifikasi responden berdasarkan umur

\begin{tabular}{ccc}
\hline Umur & Jumlah (org) & $\%$ \\
\hline$<20$ Tahun & 0 & $0 \%$ \\
20 - 40 Tahun & 22 & $88 \%$ \\
$>$ 40 Tahun & 3 & $12 \%$ \\
Jumlah & 25 & $100 \%$ \\
\hline
\end{tabular}

Sumber : Data diolah, 2018

Dari tabel 2.6 di atas terlihat bahwa dari 25 berumur antara 20 tahun sampai 40 tahun. responden yang dijadikan sampel semuanya

Klasifikasi responden berdasarkan lama bekerja

Tabel 2.7 Klasifikasi responden berdasarkan lama bekerja

\begin{tabular}{ccc}
\hline Lama Bekerja & Jumlah (org) & $\%$ \\
\hline$<3$ bulan & 0 & $0 \%$ \\
$3-12$ bulan & 8 & $32 \%$ \\
$>12$ bulan & 17 & $68 \%$ \\
Jumlah & 25 & $100 \%$ \\
\hline
\end{tabular}

Sumber : Data diolah, 2018

Tabel 2.7 memperlihatkan bahwa dari 25 bulan yakni 17 orang (68\%). Sementara responden yang dijadikan sampel didominasi sisanya adalah pegawai yang sudah bekerja oleh pegawai sudah bekerja lebih dari 12 antara 3 sampai 12 bulan yaitu 8 orang. 


\section{Tabulasi Hasil Kuesioner}

Tanggapan responden mengenai kepuasan kerja

Tabel 2.8 Deskripsi tanggapan responden terhadap kepuasan kerja

\begin{tabular}{|c|l|c|c|c|c|c|c|}
\hline \multirow{2}{*}{ No } & \multicolumn{2}{|c|}{ Item Pernyataan } & \multicolumn{3}{|c|}{ PILIHAN JAWABAN } & JML \\
\cline { 3 - 7 } 1 & & SS & S & KS & TS & STS & \\
\hline 2 & $\begin{array}{l}\text { Saya merasa bahwa kebutuhan fisiologis sudah } \\
\text { terpenuhi di perusahaan ini }\end{array}$ & 1 & 16 & 7 & 1 & 0 & 25 \\
\hline 3 & $\begin{array}{l}\text { Saya merasa diperlakukan adil di perusahaan ini } \\
\text { tersedianya jaminan kesehatan dari perusahaan } \\
\text { ini }\end{array}$ & 5 & 12 & 5 & 2 & 1 & 25 \\
\hline 4 & $\begin{array}{l}\text { Bekerja pada perusahaan ini, dapat menjamin } \\
\text { kehidupan saya dihari tua }\end{array}$ & 1 & 4 & 16 & 2 & 2 & 25 \\
\hline 5 & $\begin{array}{l}\text { Atasan saya selalu memberikan pujian apabila } \\
\text { saya menjalankan tugas pekerjaan dengan hasil } \\
\text { memuaskan }\end{array}$ & 2 & 16 & 5 & 1 & 1 & 25 \\
\hline 6 & $\begin{array}{l}\text { Saya merasa tertantang untuk menyelesaikan } \\
\text { tugas yang diberikan }\end{array}$ & 6 & 17 & 2 & 0 & 0 & 25 \\
\hline Pata-rata & 2,6 & 13,6 & 6,6 & 1,3 & 0,90 & 25 \\
\hline
\end{tabular}

Sumber : Data diolah, 2018

Dari Tabel 2.8 terlihat bahwa mayoritas responden sangat setuju terhadap variabel kepuasan kerja dengan 10,4\%. Sementara $54,4 \%$ menyatakan setuju, $26 \%$ menyatakan kurang setuju, 5,2\% menyatakan tidak setuju dan $3,6 \%$ menyatakan sangat tidak setuju. Dari hasil observasi maka di dapat jawaban sebagai berikut :
Kepuasan kerja $=10.4+54.4+26.4=$ 91,2\% sehingga berdasarkan jawaban dari responden dapat disimpulkan bahwa tingkat kepuasan kerja berada pada 91,2\% atau dapat disimpulkan bahwa para karyawan termotivasi untuk bekerja, sementara hanya $8.8 \%$ yang kurang termotivasi.

Tanggapan responden mengenai komunikasi 
Tabel 2.9 Deskripsi tanggapan responden terhadap komunikasi

\begin{tabular}{|c|c|c|c|c|c|c|c|}
\hline \multirow[b]{2}{*}{ No } & \multirow[b]{2}{*}{ Item Pernyatan } & \multicolumn{5}{|c|}{ PILIHAN JAWABAN } & \multirow[b]{2}{*}{ JML } \\
\hline & & SS & S & $\mathrm{KS}$ & TS & $\mathrm{TS}$ & \\
\hline 1 & $\begin{array}{l}\text { Saya merasa senang karena } \\
\text { karyawan di perusahaan ini bisa } \\
\text { menerima saya sebagai partner } \\
\text { yang baik }\end{array}$ & 1 & 16 & 7 & 1 & 0 & 25 \\
\hline 2 & $\begin{array}{l}\text { Saya selalu dilibatkan dalam } \\
\text { pertemuan atau rapat dalam } \\
\text { mengambil keputusan perusahaan }\end{array}$ & 1 & 17 & 5 & 2 & 0 & 25 \\
\hline 3 & $\begin{array}{l}\text { Atasan saya selalu memberikan } \\
\text { pujian apabila saya menjalankan } \\
\text { tugas pekerjaan dengan hasil } \\
\text { memuaskan }\end{array}$ & 5 & 12 & 5 & 2 & 1 & 25 \\
\hline 4 & $\begin{array}{l}\text { Saya merasa senang selama } \\
\text { pekerjaan saya diperusahaan ini di } \\
\text { akui oleh atasan }\end{array}$ & 1 & 4 & 16 & 2 & 2 & 25 \\
\hline & Rata-rata & 2 & 12,25 & 8,25 & 1,75 & 0,75 & 25 \\
\hline & Presentase (\%) & 8 & 49 & 33 & 7 & 3 & 100 \\
\hline
\end{tabular}

Sumber : Data diolah, 2018

Dari Tabel 2.9 terlihat bahwa mayoritas responden sangat setuju terhadap variabel komunikasi dengan $8 \%$. Sementara 49,9\% menyatakan setuju, 33\% menyatakan kurang setuju, $7 \%$ menyatakan tidak setuju dan 3\% menyatakan sangat tidak setuju.

Dari hasil observasi maka di dapat jawaban sebagai berikut :
Komunikasi $=8+49+33=90 \%$ sehingga berdasarkan jawaban dari responden dapat disimpulkan bahwa tingkat komunikasi berada pada 90\% sehingga dapat disimpulkan komunikasi antara karyawan berjalan dengan baik mengenai kepastian kerja, sementara hanya $10 \%$ yang kurang bisa berkomunikasi dengan baik. 
Tabel 2.10 Deskripsi tanggapan responden terhadap kinerja kerja

\begin{tabular}{|c|c|c|c|c|c|c|c|}
\hline \multirow{2}{*}{ No } & \multirow{2}{*}{ Item Pernyataan } & \multicolumn{6}{|c|}{ Pilihan Jawaban } \\
\hline & & SS & $\mathrm{S}$ & $\mathrm{KS}$ & TS & STS & $\mathrm{Jml}$ \\
\hline 1 & $\begin{array}{l}\text { Saya selalu berusaha untuk menyelesaikan pekerjaan dengan } \\
\text { penuh rasa tanggung jawab untuk mencapai hasil yang } \\
\text { maksimal }\end{array}$ & 12 & 13 & 0 & 0 & 0 & 25 \\
\hline 2 & $\begin{array}{l}\text { Saya selalu berusaha mencapai target kerja yang ditetapkan } \\
\text { oleh perusahaan }\end{array}$ & 9 & 16 & 0 & 0 & 0 & 25 \\
\hline 3 & $\begin{array}{l}\text { Saya selalu bekerja sesuai standard mutu yang telah ditetapkan } \\
\text { oleh perusahaan }\end{array}$ & 10 & 13 & 2 & 0 & 0 & 25 \\
\hline 4 & $\begin{array}{l}\text { Saya selalu berusaha menyelesaikan pekerjaan-pekerjaan yang } \\
\text { diberikan sesuai dengan target waktu kerja yang telah } \\
\text { ditentukan }\end{array}$ & 6 & 18 & 1 & 0 & 0 & 25 \\
\hline 5 & $\begin{array}{l}\text { Pengetahuan akan pekerjaan dapat membantu saya dalam } \\
\text { mengatasi permasalahan yang muncul pada saat bekerja }\end{array}$ & 10 & 15 & 0 & 0 & 0 & 25 \\
\hline 6 & $\begin{array}{l}\text { Saya dapat mengerjakan pekerjaan dengan efektif dan efisien } \\
\text { sehingga tidak perlu banyak intruksi dan umpan balik dari } \\
\text { atasan saya }\end{array}$ & 7 & 13 & 5 & 0 & 0 & 25 \\
\hline 7 & $\begin{array}{l}\text { Kreativitas yang tinggi dapat membantu saya mencapai hasil } \\
\text { kerja yang lebih baik }\end{array}$ & 9 & 15 & 1 & 0 & 0 & 25 \\
\hline 8 & Saya selalu memberikan ide-ide untuk kemajuan perusahaan & 5 & 13 & 7 & 0 & 0 & 25 \\
\hline 9 & $\begin{array}{l}\text { Saya selalu bersedia untuk bekerja sama dengan sesama } \\
\text { karyawan perusahaan lain }\end{array}$ & 7 & 18 & 0 & 0 & 0 & 25 \\
\hline 10 & $\begin{array}{l}\text { Saya selalu berusaha menyelesaikan pekerjaan lebih cepat dari } \\
\text { waktunya agar saya dapat mengerjakan pekejaan berikutnya }\end{array}$ & 7 & 17 & 1 & 0 & 0 & 25 \\
\hline 11 & $\begin{array}{l}\text { Saya selalu hadir tepat waktu sesuai dengan jadwal yang sudah } \\
\text { ditetapkan ditempat kerja }\end{array}$ & 1 & 17 & 5 & 2 & 0 & 25 \\
\hline 12 & $\begin{array}{l}\text { Saya memiliki semangat untuk melaksanakan pekerjaan- } \\
\text { pekerjaan baru yang diberikan oleh perusahaan }\end{array}$ & 4 & 21 & 0 & 0 & 0 & 25 \\
\hline & Rata-rata & $\begin{array}{c}7,2 \\
5\end{array}$ & $\begin{array}{l}15, \\
75\end{array}$ & 1,83 & 0,17 & 0 & 25 \\
\hline & Presentase $(\%)$ & 29 & 63 & 7,32 & 0,68 & 0 & 100 \\
\hline
\end{tabular}

Sumber : Data diolah, 2018 
Dari hasil observasi kinerja kerja pada Tabel berikut : Kinerja kerja $=29+63+7,32=$

2.10 terlihat bahwa $29 \%$ menyatakan setuju, $63 \%$ menyatakan sangat setuju, $7,32 \%$ menyatakan kurang setuju, dan sisanya $0,68 \%$ menyatakan tidak setuju. Dari hasil observasi maka di dapat jawaban sebagai
99,32\% sehingga berdasarkan jawaban dari responden dapat disimpulkan bahwa tingkat kinerja kerja berada pada 99,32\% mempunyai kinerja yang baik, sedangkan $0,68 \%$ mempunyai kinerja kurang baik.

PRESENTASE KETIDAKHADIRAN KARYAWAN PT. ZTE INDONESIA PERIODE JANUARI - JULY 2018

Tabel 2.11 Presentase Ketidakhadiran Karyawan

\begin{tabular}{|c|c|c|c|c|}
\hline \multirow{2}{*}{ Bulan } & \multicolumn{3}{|c|}{ Presentase Ketidakhadiran Karyawan (\%) } & \multirow{2}{*}{ Jumlah $(\%)$} \\
\hline & Sakit & Ijin & Alfa & \\
\hline Januari & 3.9 & 4.5 & 0.4 & 8.8 \\
\hline Februari & 2.9 & 2.1 & 0.6 & 5.6 \\
\hline Maret & 5.8 & 5.1 & 0.7 & 11.6 \\
\hline April & 2.6 & 2.3 & 0.8 & 5.7 \\
\hline Mei & 3.5 & 2.2 & 0.7 & 6.4 \\
\hline Juni & 3.1 & 3.3 & 2.1 & 8.5 \\
\hline July & 3.7 & 5.1 & 1.7 & 10.5 \\
\hline Jumlah & 25.5 & 24.6 & 7 & 42.7 \\
\hline Rata-rata & 3.64 & 3.5 & 1 & 6.1 \\
\hline
\end{tabular}


Rendahnya angka turn over dan cukup rendahnya intensitas ketidakhadiran karena sakit ijin dan alfa menunjukan bahwa kinerja dan motivasi kerja tinggi. Berdasarkan halhal tersebut diatas yakni

Pengamatan/observasi langsung terhadap karyawan di lingkungan PT. ZTE Indonesia pada bagian Departement Quality Control, Project, Umum, dan pada semua ruangan kerja lingkungan kantor.

Wawancara/interview langsung dengan karyawan PT. ZTE Indonesia pada bagian Human Resource Departement, Staff Umum, Roll Out Manager.

Cross check atas ketentuan dan kebijakan perusahaan yang diberlakukan kepada karyawan.

Data dari Human Resource Departement.

Dapat disimpulkan bahwa motivasi kerja karyawan PT. ZTE Indonesia cukup tinggi. Hal ini sesuai dengan pendapat yang dikemukakan oleh David McClelland dalam A. A. Anwar Prabu Mangkunegara (2001 : 103) bahwa terdapat 6 karakteristik orang yang mempunyai motif berprestasi tinggi yaitu; memiliki tingkat tanggung jawab pribadi yang tinggi, berani mengambil dan memikul resiko; memiliki tujuan yang realistik; memiliki rencana kerja yang menyeluruh; memanfaatkan umpan balik yang konkret dalam semua kegiatan yang dilakukan dan mencari kesempatan untuk merealisasikan rencana yang telah diprogramkan. Dalam kaitannya dengan ini, karyawan PT. ZTE Indonesia mempunyai ciri-ciri tersebut, sehingga termasuk mempunyai motivasi berprestasi tinggi.

\section{PENUTUP}

\section{Kesimpulan}

1. Berdasarkan analisa yang penulis dapatkan bahwa kepuasan kerja adalah 91,2\%, komunikasi 90\%, kinerja kerja 99,32\% dan dikaitan dengan tingkat kehadiran karyawan 93,9\% maka dapat disimpulkan bahwa karyawan PT.ZTE Indonesia mempunyai motivasi yang tinggi terhadap pekerjaan mereka.

2. Berdasarkan pengamatan/observasi hal ini memang dibuktikan langsung terhadap karyawan di lingkungan PT. ZTE Indonesia, melalui Wawancara/interview langsung dengan karyawan, dan data yang didapatkan dari Human Resource Departement dan menganalisa langsung maka dapat disampaikan bahwa, motivasi kerja karyawan PT. ZTE Indonesia cukup tinggi. 


\section{Saran}

Berdasarkan hasl dari observasi ini, maka saran kepada manajemen PT. ZTE Indonesia sebagai berikut :

1. Mengadakan rolling karyawan antar bagian guna menghindari kejenuhan kerja, agar tingkat motivasi kerja karyawan selalu terjaga pada level yang tinggi.

2. Menerapkan sistem pensiun dini bagi karyawan yang sudah lanjut usia.

3. Mengadakan penjelasan atau klarifikasi tentang kesejahteraan karyawan yang bersifat normatif dan bersifat non normative agara seluruh karyawan dapat memahami, sehingga tidak terjadi kesalahpahaman tentang kesejahteraan karyawan yang diberikan oleh manajemen perusahaan.

\section{DAFTAR PUSTAKA}

Arikunto, Suharsimi. 2008. Prosedur Penelitian. Jakarta : Rineka Cipta.

As'ad, Moh. 2008. Psikologi Industri. Yogyakarta : Liberty

Dessler, Gary. 2008. Terjemahan Agus
Dharma. Manajemen Personalia. Jakarta : Erlangga.

Handoko T. Hani dan Sukanto Reksohadiprojo. 2008. Teori dan Perilaku Organisasi Perusahaan. Yoyakarta : BPFE UGM.

Hasibuan, Malayu SP. 2008. Organisasi dan Motivasi. Jakarta : Bumi Aksara. Keraf, Gorys.2001. Komposisi. Jakarta : Nusa Indah.

Mangkunegara, A. A. Anwar Prabu. 2008. Manajemen Sumber Daya Perusahaan. Bandung : Remaja Rosdakarya.

Robins, Stephen P. 2008. Perilaku Organisasi. Jakarta : PT. Prenhallindo.

Siagian, Sondang P. 2008. Manajemen Sumber Daya Manusia. Jakarta : Bumi Aksara.

Sulistiyani, Ambar T. dan Rosidah. 2008. Manajemen Sumber Daya Manusia. Yogyakarta : Graha Ilmu.

Tery, G.R. 2008. Asas-asas Manajemen. Bandung : Alumni.

Wahjosumidjo. 2008. Kepemimpinan dan Motivasi. Jakarta : Ghalia Indonesia.

Winardi, J. 2008. Motivasi Dan Pemotivasian Dalam Manajemen. Jakarta : PT. Raja Grafindo Persada. 